because the powers they have rel ased have not been rightly used in the service of mankind as a whole.

It is at this point that Sir Richard's address is linked up with an article "Science to Re-build" in the November issue of Current Science (India). Admittedly the Atlantic Charter gives new hope for the establishment of a world order in which the fundamental rights of men and communities will be defined and acknowledged and in which science will be able to serve more effectively the needs of mankind. Such rights and principles must, however, be formulated more clearly than has yet been done if reconstruction is to prove effective, and science can well combine with politics, as Sir Richard suggests, in the determination of such principles and in arriving at a sound basis for the constitution and judgments of a court of international politics.

The article in Current Science indicates further steps to be taken, notably in the extension of scientific knowledge in those fields where it would assist man to acquire control over his own nature corresponding with his control over material resources. Besides, it is essential that even such declarations as the Atlantic Charter should be submitted to careful and scientific scrutiny. Already there have been some differences of interpretation of, or at least of emphasis on, the various clauses and if misunderstandings are to be avoided certain of these points must be elucidated in the near future.

In the modern world to-day not even an AngloAmerican declaration of policy can avoid facing the colour question, and the article in Current Science is on firm ground in directing attention to the omission of any reference to such countries as India, and again in insisting that the first axiom in world planning is that the prime motive force of life is hunger, which knows no distinction of colour. No world order which does not take into account the needs of coloured as well as of the white races can be regarded as either scientific or durable.

On other specific points of the Atlantic Charter this article is equally searching. In regard to territorial settlements it points out that an expert body of economists, demographers and other specialists will be required to furnish the necessary advice on particular settlements if such settlements are to be free from any sense of unfairness. It challenges the durability of any settlement respecting the right of all peoples to choose the form of government under which they will live, unless in practice that government is some form of democracy. It raises the question of the responsibility of scientific men in respect of disarmament with reference to work likely to be useful for military purposes, and suggests that such researches should be submitted for examination and their report on results for control by an international agency.

In the field of economic development some of the implications of the Charter are indicated, such as open markets, the supply of technical knowledge and skill and industrial machinery, and an international bank or finance corporation to lend money for development purposes, free from political, military or trading obligations.
It is abundantly clear that there is an immense field in which fundamental thinking is required before we can implement many of the principles of the Atlantic Charter or assess rightly the schemes of reconstruction which must be worked out in readiness even in the dark and exacting days of war. To that thinking science has much to contribute. Corporately and individually scientific workers can also do much to forward the task of reconstruction in fields where they bear special responsibility, as has already been recognized by engineers, physicists, medical men and architects in the formation of special planning committees or commissions. There are, however, many sections of scientific workers who have shown little sign of recognition of their responsibility in this field and it may well be hoped that Sir Richard Gregory's address will not only stimulate such to action, but also scientific workers generally, to consider more carefully the appropriateness and effectiveness of the machinery which already exists for integrating the relations of science and politics, whether at the top in the Scientific Advisory Committee, in the arrangements for widening the outlook and experience of the active young minds engaged in scientific work, to which Prof. A. V. Hill has specially referred, or in that fundamental task of educating the public mind so that it can reach sound decisions and supply the power to overcome private interests which hold up action demanded by the public interest. As these lines are explored with the world vision and perspective which Sir Richard emphasizes, the relations between science and politics will become more clearly delineated, while the claims of science to be free from any form of pressure in pursuing her work are established beyond challenge.

\section{SKILLED MAN-POWER IN THE SERVICES}

THE importance of wise utilization of skilled man-power if we are to develop the maximum production and war effort has been emphasized by recent events, and its realization has been implicit. throughout recent debates and discussions in Parliament and elsewhere. If the second report of the Beveridge Committee on Skilled Men in the Services* will not altogether dispel misgivings on that ground, there are certain points on which it gives welcome reassurance.

The Committee is able to answer unhesitatingly that the Navy is using the skilled man-power at its disposal with due economy and effect, except in regard to naval reservists, where the measures already taken for transfer of qualified men to skilled work need to be repeated and reinforced until they achieve success. Better use is being made of skilled engineers in the Navy than in either the Army or Air Force. Although the problems in the Navy are simpler, they would not be solved as completely as they are, unless the Navy possessed, as it does, good

* Committee on Skilled Men in the Services: Second Report and a Memorandum by the War Office. Pp. 74. (London: H. M. Stationery Office, 1242.) 18. $3 d$. net. 
arrangements in respect of trade testing, search for talent, technical training, review of establishments, interim use of engineers and self-scrutiny. The trade testing of the Navy is centralized, standardized, and objective. Any skilled engineer volunteering for the Navy knows that he will have a fair test,s and that if he passes, he will be ranked forthwith as a petty officer and employed as an engineer. There is organized search for talent in the Navy and, while in the development of new training establishments the Navy has less to show than either of the other Services, the regular establishments are excellent and their procedure has been adjusted to war conditions. By better use of some of the naval reservists, the Committee estimates that it should be possible to meet some 10 per cent of the demands of the Navy for skilled men during the period ending March 31, 1942 , but substantial additional numbers will be required.

The Air Force stands intermediate between the older Services, in size, in rate of expansion, and in the complexity of its problems. It is also not so clear of complaints of unused skill as is the Navy; but, while it has nothing comparable in scale to the misfits and misapplications that appear in some parts of the Army, it shows sufficient misfits to call for expansion of the measures which have already been taken to deal with such cases. The Committee considers that the machinery for sorting, selecting and trade testing should be re-examined, and such barriers as remain should be reconsidered.

The situation with regard to the Army is less satisfactory, and substantial changes of organization and machinery are likely to be required before it can be said that the skilled man-power already at the disposal of this Service is being used with due economy and effect. There are, of course, several factors which have made the adjustment of supply to demand and full use of skilled men harder for the Army than it is for either of the other Services, or for civilian industry. The Army has expanded more than either of the other Services and much more than the munitions industries, and its rate of growth has been subject to violent fluctuations. An industrial organization which after a comparable period of growth was subjected to a similarly thorough scrutiny would be lucky it it failed to show many misfits.

At the beginning of the War, the Army received numbers of men, either called up as territorials and reservists or posted as militia, in regard to whom it was not possible to exercise selection in assigning them to appropriate trades or units. In addition, the Army, while growing, has had to change its character by progressive increase in the proportions of armoured and mechanized divisions. The character of the War, with the serious loss of equipment in France and the subsequent prolonged restoration and waiting in England, have added to the difficulties of adequate use of the man-power in the Army, but one of the most fundamental difficulties is the structure of the Army as a combination of distinct corps and of units, often with strong local associations or sectional traditions, and consequent obstacles to transfer.
All the investigations of the Committee point to the conclusion that the reservoir of unused engineering skill already in the Army is greater than the revised requirements for skilled men of engineering and allied occupations laid before it by the War Office. While this does not mean that all such requirements can be met from within the Army, it does involve certain major changes, notably the technical review of establishments, the pooling of mechanical reserves, and the reorganization of selecting, sorting and tradetesting arrangements. The older Army training establishments are regarded as excellent. Its new training establishments are an improvisation deserving of great praise; good in themselves, they need to be fitted more closely into the organization of the Army as a whole, with better selection of trainees and with closer adjustment to the practical problems which the trainees will have to solve.

The report advances two major proposals for consideration, rather than as recommendations : enlistment into the Army not for corps, but as a single Service; and the establishment of a Corps of Mechanical Engineers. Fundamental to this and to the vital changes recommended, and a condition of their achievement, is that mechanical and electrical engineering, as distinct from civil engineering, should be given their proper place and authority in the higher councils of the Army. Review of establishments on the lines suggested may achieve substantial economies of skilled men in the Army without undue risk, but the vital need is for a new outlook, for new methods for new tasks. Mechanization of an army, as the Committee observes, should begin from the top.

When full allowance has been made for all disturbing factors, and in spite of the vigorous efforts made in all three Services to bring about a re-mustering and using of men according to their skill, the extent to which men of rare skill find that skill unused in the Forces, in the Committee's judgment, remains disturbing and surprising. It is fully recognized that many forms of skill which are valuable in peace cannot be turned to account in war, and that the essential problem of skilled men in the Services is that of how to be ready for emergencies without wasting more than the irreducible minimum of skill in standing-by. The organization of war is largely a question of priorities, and in regard to engineers the Committee has been guided by two principles: the first priority in war is for whatever may be needed to keep the machines of war in action; and second, in war engineers are for those who can and will use them as engineers.

The Committee points out that, on the first principle, skilled engineers and spare parts are alternative means of securing the maintenance of machines of war, and its lucid argument shows a clearer grasp than the War Office in its accompanying memorandum of what General Wavell termed the "mechanism of war" and the real foundation of military knowledge in his lectures on "Generals and Generalship". While, therefore, the full investigations leave unchanged the main conclusion of the interim report that an increase in the skilled personnel of the 
Services is inevitahle, and that more engineers must be drawn from civilian industry for the Services, there is a clear possibility that the unused reservoir of engineering skill in the Army is large enough and varied enough to meet all the requirements submitted to the Committee for men of engineering skill.

The whole tone of the War Office memorandum published with the report betrays a disquieting failure to see the situation in its true perspective of either time or resources, and the subsequent speech by the Secretary of State for War in the House of Commons was even less reassuring. Some of the points raised in the War Office memorandum deserve careful consideration, but a frame of mind and a condition of organization which have already taken three and a half months to produce this memorandum on the report with the remark that so important a recommendation as the creation of a Corps of Mechanical Engineers is still under consideration are profoundly disturbing. The War Office cannot avoid the issue by the naive suggestion that the Beveridge Committee brings to its task merely the standards of industrial practice. The problem of a trained, equipped and maintained army and its industrial background must be seen as a whole, and if the Army's present leaders cannot see the problem thus and weed out wasters as well as waste at every rank, they must be replaced by those who can.

It should not be thought, however, that in spite of the procrastination of the higher command in dealing with the two major proposals, the Army is making no attempt at a more scientific use of its resources of man-power, skilled or unskilled. Lieut.General Sir Ronald Adam recently gave an encouraging account of the selection tests for avoiding misfits which have already been developed under the Advisory Committee, composed of Prof. J. Drever, Dr. C. S. Myers, Prof. F. C. Bartlett and Prof. C. Burt, appointed last June to assist the Director of Personnel Selection. Moreover, a thorough analysis is being made of every job in the Army and experiments are being made in leadership tests, based to some extent on German practice, for use in selecting men for training as officers, and directed to ensuring that a leader is more intelligent, has quicker reactions and more personality than the men he leads.

General Adams's statement that a large-scale experiment has been started by enlisting men into a general service corps and putting them through a basic training course before deciding for which corps they are best suited indicates a greater receptivity to new ideas than is apparent in the War. Office mernorandum.

A more promising attitude is also to be found in the War Office observations on the twenty-second Report of the Select Committee on National Expenditure, which have now appeared in the Select Committee's first report of the 1941-42 Series. The memorandum states that the directorate of Selection of Personnel has a staff of 15 officers and 150 N.C.O.s (including A.T.S.) and has been approved to carry out selection tests on the personnel both of intakes and of existing units. While upholding the value of the military interview, the memorandum recognizes that the selection test is complementary and that the value of the interview will be greatly increased if the interviewing officer has before him the result of the man's selection test. The War Office would welcome a system of compulsory intelligence testing of all intakes, regardless of their preference, to.be carried out under the auspices of the Ministry of Labour.

Discussing the Select Committee's recommendation for the establishment of central depots for classification before posting, the same argument is advanced as that against the proposal of the Beveridge Committee, but it is admitted that the basic training centre system is already in use for the A.T.S. As regards the discharge of unsuitable personnel, the War Office urges that this must be weighed carefully against the man-power situation. The War Offce agrees that intelligence is one of the principal factors in the make-up of a potential officer, and that no candidate should be sent to an officer cadet training unit whose intelligence as measured by a test does not reach a certain standard. The time to apply such a test is under investigation, and it is proposed that all candidates should be given an intelligence test before their interview by a Command Interviewing Board.

These observations will do something to reassure opinion as to the readiness of the Army to rectify past mistakes and improve its technique and organization in these vital matters. Sir Edward Grigg's speech following Capt. Margesson's in the debate on the Army Estimates, was, however, somewhat disturbing from the point of view of the outlook betrayed. The statement that only 9 per cent of officers in the Army had had a university education can reflect equally on the capacity of the universities to train men for leadership and on the ability of the Army to recognize potential leaders. But it cannot be discussed without some knowledge of the numbers of university men available for meeting Army requirements and of the extent and nature of the Army's requirements for officers.

The statement should not be allowed to pass unnoticed, because of the implication contained in the whole context that a high standard of education is unnecessary in meeting Army requirements. Fundamentally, it may well be found that the blows which we have recently suffered are due at least in part to defects of leadership from top to bottom of the Services, which can in turn be traced to the neglect and indifference of people and Government alike to the real issues of education. Sir Edward Grigg fundamentally misconstrued the attack on recruitment of officers from the public schools. The objection to that system is that it places recruitment on a class basis, and does not tap the larger reserves of leadership available in the nation. Moreover, until some system of intelligence test is imposed in accordance with the War Office memorandum, on all entrants to officers training establishments, from Sandhurst and Woolwich downwards, there will be no satisfactory obstacle to such factors as social or economic position admitting men ultimately to positions of responsibility which they lack the character or ability to discharge. 
The appearance of the Beveridge Report and the accompanying memorandum, however, should not be without a steadying influence on the public mind. They represent a great challenge to constructive thought which scientific workers should be quick to accept. Their implications strike far into the causes of our present difficulties, and there are few indeed who cannot see in this analysis some bearing on their own task and part in the war effort, and an indication of how that contribution can be increased. The solid reasons for confidence contained in the Report, and the picture of admirable work already being done, only emphasize the urgency for doing quickly what more remains to be done. On every citizen lies the responsibility for seeing that there is no waste of skill, men or material, and when he has done his or her utmost in his own special sphere, there lies that corporate responsibility of compelling effective and urgent action, through Parliament and the sheer force of public opinion, wherever indifference, neglect, incompetence or lack of interest perpetuates inefficiency and waste.

\section{FIREFLIES}

\section{Living Light}

By E. Newton Harvey. Pp. $x v+328$. (Princeton, N.J. : Princeton University Press ; London : Oxford University Press, 1940.) 24s. net.

A GLOW-WORM in the grass and fire dripping from the oar are two things which once seen are never to be forgotten. Faraday, posting through Italy with Sir Humphry Davy, found "entertainment and delight" in the fireflies by the way. When the Challenger entered the Guinea Current, soon after her voyage began, the sea was "a perfect blaze of phosphorescence"; and long afterwards Wyville Thomson used to tell us how the Pyrosomas glowed in the water like bars of white-hot steel. Sir Joseph Banks had found his Medusa pellucens (akin to our Pelagia noctiluca) in the same waters, and thought it the most splendid of the luminous inhabitants of the ocean; its flashes of light, he said, were so vivid as to affect the sight of the observer. And Humboldt speaks with his great voice of that "magic brightness", which is part of the joy of those who, like himself, have a peculiar predilection for the sea.

The shellfish (Pholas) which, according to Pliny, seem on fire as they go down your throat-velut igne lucentes in tenebris, etiam in ore mandentium; the splendid brief intensity of the Bermuda fireworm; the little lanterns of the deep-sea fish which the dredge brings up and which Dr. Beebe goes down to see; the little squid at Messina which surround themselves with liquid fire instead of a screen of ink - all these are part of the multitudinous phenomenon which Prof. Newton Harvey lovingly and enthusiastically describes. Every now and then our wonderment grows greater still over some new feature of the display, such as the flashing of certain fireflies in periodic synchronism. "At one time [in Siam] every leaf and branch appears decorated with diamond-like fire; but soon there is darkness, to be again succeeded by flashes from innumerable lamps."

For thirty years at least Prof. Newton Harvey and the students in his Princeton laboratory have been studying the phenomena of luminescence. They have turned out among them a host of well-known papers, and his friend, Prof. Ulric Dahlgren, has been as busy on the histological side as Prof. Harvey on the experimental and biochemical ; indeed, Prof. Harvey seems just a little weighed down in the writing of this book by the superabundance of his own knowledge. $\mathrm{He}$ gives us a useful bibliography of some thirty pages; but this, he tells us, is a mere nothing, so vast is the literature of the subject. A hundred years ago, in his famous work, "Das Leuchten des Meeres", Ehrenberg cited between four and five hundred older books and papers, very few of which Prof. Harvey finds room, or thinks it necessary, to quote again.

But to sum up. After giving a third of his book to the description of all manner of phosphorescent organisms, Prof. Harvey goes on to deal with the physics, the chemistry and the physiology of the subject. $\mathrm{He}$ describes the various types of lumin. escence from the physicist's point of view. He goes on to the chemistry of luminescence, and is particularly interested in the curious substance described sixty years ago by Dubois as luciferine, along with its enzyme luciferase. An interesting chapter follows on the physiology of luminescence; and the last chapter of all (which interests me less) is on the physical nature of light. Of the many illustrations, some are curiously beautiful, especially the frontispiece, which shows some of Dr. Beebe's deep-sea fishes in pursuit of little scarlet and luminous squid.

The author is generous in crediting to its discoverer almost every fact which he records; but it cramps his literary style somewhat to quote fifteen or eighteen authors on a page, along with the dates of their several publications. The book has its share of misprints, but its blunders, so far as I can see, are few. The Nemertean worms are not so called from the 'unerring' aim of their proboscides, but merely as a literary allusion to Hesiod's description of the father of all the Nereids, the wise Old Man of the Sea. And as to Fulgora, whose time-honoured reputation as a 'lantern-fly' now comes in question, it would be all very well to call it a 'bug', but to call it a beetle won't do.

D'Arcy W. Thompson.

\section{THE LIVING SPIDER}

\section{The Comity of Spiders}

By Dr. William Syer Bristowe. Vol. 2. (Ray Society Volume for the Year 1940.) Pp. xiv $+229-560+3$ plates. (London: Bernard Quaritch, Ltd., 1941.) 25s. net.

A LTHOUGH Dr. Bristowe writes in his preface A that the War has affected his work on spiders and even his enthusiasm it is difficult for the reader to detect many signs of this in the volume which concludes the work first published in 1939. The subjects with which he is now concerned are food and its capture, danger and its avoidance, courtship and mating. On these matters he gives us a summary of his own investigations-which began, he tells us, at the age of four-supplemented by some contributions from the work of other araneologists.

In the first chapter, which deals with the capture of the prey, Dr. Bristowe analyses the varied methods 